\title{
Molecular Basis of Synovial Sarcoma and the Rare Case of its Localization in Palatine Tonsil: A Review of the Literature
}

\section{Nikolaos Andreas Chrysanthakopoulos ${ }^{1 *}$ | Eleftheria Vryzaki ${ }^{2}$ | Kyriakos Karkoulias ${ }^{3}$}

*Correspondence: Nikolaos Andreas Chrysanthakopoulos

Address: ${ }^{1}$ Dental Surgeon, DDSc, -Oncologist (MSc), Specialized in Clinical Oncology, Cytology and Histopathology, Dept. of Pathological Anatomy, Medical School, University of Athens, Athens, Greece, Resident in Maxillofacial and Oral Surgery, 401 General Military Hospital of Athens, Athens, Greece, PhD in Oncology (cand); ${ }^{2} \mathrm{MD}, \mathrm{PhD}$, Department of Dermatology, Rio University Hospital of Patras, Greece; ${ }^{3}$ Associate Professor, MD, PhD, Department of Pulmonary Medicine, Rio University Hospital Faculty of Medicine, University of Patras, Greece e-mail $\bowtie$ nikolaos_c@hotmail.com,nchrysant@med.uoa.gr

Received: 12 November 2021; Accepted: 23 November 2021

Copyright: (C) 2021 Chrysanthakopoulos NA. This is an open-access article distributed under the terms of the Creative Commons Attribution License, which permits unrestricted use, distribution, and reproduction in any medium, provided that the original work is properly cited.

\section{ABSTRACT}

Synovial sarcomas (SS) are rare soft tissue malignant tumors that mainly arise from the lower extremities, especially the lower thigh-knee region. The literature has shown that this tumor may be observed in uncommon regions such as the abdominal wall and the head and neck region which are non-synovium-lined spaces. SS rarely occurs in the head and neck region, as only $3-10 \%$ of these neoplasms appear in this region. The parapharyngeal space is the most common location, whereas primary SS of the palatine tonsil is extremely rare as only a few cases of primary tonsillar SS have been described. It is considered as a high grade malignant tumor, however current investigation regarding its clinical and histopathological features revealed in all these cases a biphasic morphology. Molecular analyses detected a typical SYT gene t(X;18) (p11; q11) translocation and a representative SYT/SSX1fusion type. Immunohistochemical analysis recorded cytokeratin OSCAR, Bcl-2, EMA, vimentin, TLE1 and PGP 9.5, were diffusely positive. The aim of the current review was to present the molecular basis of SS and SS rare location in palatine tonsil.

Keywords: Synovial Sarcoma, Translocation, Molecular Biology, Tonsil

\section{Introduction}

Synovial Sarcoma (SS) is a mesenchymal tumor characterized of spindle cells that show changeable differentiation of the epithelial component, including gland formation, and a specific chromosomal translocation $\mathrm{t}(\mathrm{X} ; 18)$ (p11; q11). It is thought to arise from pluripotent mesenchymal cells with both epitheloid and spindle differentiation (Fisher et al., 2002). SS is the fourth most frequent soft tissue sarcoma after liposarcoma, malignant fibrous histiocytoma, and rhabdomyosarcoma (Enzinger and Weiss, 2001). Despite the term, SS has no association with synovium and may occur at any site of the human body, mostly in the deep soft tissue of body limbs (80\%) (Eilber and Dry, 2008). SS rarely appears in the head and neck location, as only $3-10 \%$ of these neoplasms have been found in this region 
(Fisher et al., 2002; Vogel et al., 2007; Vogel et al., 2010), especially in the cervical and parapharyngeal region (Dei Tos et al., 1998), whereas it has been revealed in the trunk (8\%) and retroperitoneal/abdominal region (7\%), which are the most frequent non-extremity primary sites of the tumor (Clair JM et al., 2016). The most common locations in the head and neck region are hypopharynx, parapharyngeal space and posterior pharyngeal wall. Primary palatine tonsillar SS is extremely rare and only a few adult cases have been described up to now, whereas it is responsible for $5-10 \%$ of soft tissue sarcomas (Khademi et al., 2010; Vogel et al., 2010; Soria-Cespedes et al., 2013). SS can develop at any age, is typically observed in adolescents, however is most commonly observed in young adults, and the annual incidence rate is $0.5-7 /$ million in children and adolescents younger than 20 years of age (Okcu et al., 2003). The origin of SS is uncertain, since the normal cellular transcript for this tumor is unknown. Some reports suggest that SS arises from a mesenchymal stem cell with ability for epithelial differentiation (Noguchi et al., 1997; Yakushiji et al., 2000). SS is characterized by four histologically subtypes, monophasic fibrous tumor, biphasic tumors, monophasic epithelial tumors, and poorly differentiated tumors (Tsuji et al., 1998).

\section{Synovial Sarcoma Molecular Basis}

SS monophasic variant mainly composed of mesenchymal spindle cells with or without solid epithelial regions (Clark et al., 1994; Meis-Kindblom et al., 1996), and the biphasic variant contains various rates of epithelial cells arranged in a glandular configuration in a background of mesenchymal spindle cells (Clark et al., 1994; Gaertner et al., 1996).

Molecular analyses disclosed a typical $\mathrm{t}(\mathrm{X} ; 18)$ (p11.2; q11.2) translocation (Turc-Carel et al., 1987). The presence of the mentioned chromosomal translocation has been observed at a rate higher than $90 \%$ of SS cases (Turc-Carel et al., 1987; Sreekantiah et al., 1994), and is proposed to be the primary causal element in SS cases (Ladanyi et al., 2002).

Cloning of the breakpoints of this translocation revealed the fusion of two genes, SYT that is located on chromosome band 18q11 and SSX that is located on Xp11 chromosome region (Clark et al., 1994). The SYT gene is fused with one of three closely associated genes, SSX1, SSX2, and in rare cases SSX4 (de Leeuw et al., 1995), located on chromosome X in the vicinity of ornithine amino- transferase like (OATL) pseudogene 1 and 2 (Xp11) (de Leeuw et al., 1995; Crew et al., 1995). The frequency of SYTSSX4 fusion still remains unknown.

Whether the accurate location of the $\mathrm{X}$ chromosome breakpoint links with the histological morpho- logy of SS has been discussed for some time. It has been hypothesized (Kawai et al., 1998) that 
a significant association between histological subtype, monophasic and biphasic, and the type of SYTSSX fusion transcript exists. The SYT/SSX1 translocation is correlated with the biphasic and monophasic histological subtypes, whereas the SYT/SSX2 translocation is commonly correlated with only the sarcomatous (monomorphic) pattern (Thaete et al., 1999; Ladanyi et al., 2002; Kato et al., 2002). However, other researchers (Willeke et al., 1998) failed to confirm such findings.

Consequently, it has been recommended that precise functional differences between SYT-SSX1 and SYT-SSX2 may influence the epithelial differentiation in these sarcomas. Supposedly, the differences in 13 amino acids of the carboxy-terminal end of SYT-SSX1 and SYT-SSX2 proteins may influence specific protein-protein interactions that may lead to differentiation of SS (Kawai et al., 1998; Willeke et al., 1998; Antonescu et al., 2000; Ladanyi et al., 2001; Ladanyi et al., 2002). The biological basis of those observations is still unclear, and this model requires experimental confirmation. Fluorescence in situ hybridization (FISH) laboratory technique is used for detecting and locating a specific DNA sequence on a chromosome. After performing that technique an association was proposed from three independent groups between the two histologic subtypes of SS and breakpoints in the OATL1 or OATL2 region, now known to comprise the SSX1 and SSX2 genes, respectively (de Leeuw et al., 1994; Renwick et al., 1995). However, similar reports failed to confirm those findings (Crew et al., 1995; Shipley et al., 1994; Shipley et al., 1996).

Moreover, recent microarray-based expression profiling reports of SS have recognized genes that show different expression between SS and other Synovial Cell Sarcomas or biphasic and monophasic histological subtypes (Allander et al., 2002; Nagayama et al., 2002; Nielsen et al., 2002). The fused genes are responsible for a chimeric protein in which 8 amino acids of the carboxy- terminal end of SYT are substituted by 78 amino acids from the carboxy-terminal end of either of the SSX proteins. Five highly homologous SSX genes (SSX1-5) have been detected, and are localized on chromosome region Xp11.2 (Crew et al., 1995; de Leeuw et al., 1996; Gure et al., 1997).

There is limited information regarding the operating role of the mentioned proteins in cancer pathogenesis. Similar to other chromosomal translocations in sarcomas the mentioned translocation leads to the formation of a chimeric protein that possibly deregulates the transcriptional factors such as CRB/p3006 and hBRM/hSNF2a, a component of the SWI/SNF complex that regulates chromatin remodeling (Ladanyi, 1995; Thaete et al., 1999; Nagai et al., 2001; Kato et al., 2002). In the SYT-SSX fusion transcript, the amino-terminal repressor domain of $S S X$ is substituted by the carboxy-terminal domain of SYT, which has been found to act as a transcriptional activator (Brett et al.,1997). The chimeric protein, SYT-SSX, which has been localized in the nucleus, possibly deregulates the 
transcription of other genes, whose identity has not yet been clarified, especially through proteinprotein interaction, as they seem to lack DNA-binding domains (dos Santos et al., 1997). In agreement with the intracellular location of transcriptional regulators, SYT, SSX, and SYT-SSX are nuclear proteins (dos Santos et al., 1997). Moreover, the SSX1 and SSX2 amino-terminal regions comprise a repressor domain that acts as inhibitor of transcription (Brett et al., 1997).

In the chimeric transcript of SS this repressor domain, encoded by the 5 part of SSX1 and SSX2, is replaced by all but the 3-end of SYT, an extensively expressed gene encoding a region that can act as a transcriptional activation domain (Brett et al., 1997).

The amino-terminal regions of SSX1 and SSX2 proteins, that are not maintained in the fusion proteins, contain two well-maintained domains. The first one is similar to Krüppel-associated box-A (KRAB) domain (Crew et al., 1995), and the other is located in the carboxy-terminal, and both of which show suppression activity. Moreover, KRAB domain is not maintained at the fusion with SYT (Lim et al., 1998).

It is possible that SSX1 and SSX2 genes come from a relatively current duplication process and encode proteins with remarkable homology, 81\%. Recently, additional related SSX genes, obviously not involved by the mentioned translocation, have been recognized in Xp11 location (de Leeuw et al., 1996; Chand et al., 1995).

The biological functions of normal SYT and SSX proteins are to a great degree unknown. However, it has been demonstrated that the wild-type SYT and SSX proteins have an active role in the process of transcription through interactions between proteins, despite the fact that they do not have direct DNAbinding domains, as already mentioned (Brett et al., 1997; dos Santos et al., 1997). The normal SYT gene is extensively expressed in a wide diversity of cell types during early embryogenesis (Bruijn et al., 1996), however the function of the proteins is unknown. The SYT gene is widely expressed in human tissues, whereas the SSX genes seem to be expressed only in testis and thyroid (Crew et al., 1995; Türeci et al., 1996).

Within the carboxy-terminal part are three supposed Src homology (SH) binding domains (Clark et al., 1994). The presence of these SH binding domains suggests that SYT is implicated in intracellular signaling pathways. Moreover, research on other translocations showed (Rabbitts, 1994) that the affected genes often encode transcription factors. Consequently, it has been suggested that the SYT gene may encode a transcription factor (Clark et al., 1994).

SSX2 gene expression has also been revealed in melanoma (dos Santos et al.,2000), whereas 
recently, other related SSX genes have been revealed, but they are not implicated in the mentioned trans- location in SS cases (Smith and McNeel, 2010).

E74 Like ETS Transcription Factor 3 (ELF3) is a protein that in humans is encoded by the ELF3 gene that belongs to ETS transcription factors family, and is implicated in epithelial differentiation control. A great amount of genes that their expression occurs in the epithelium contain consensus binding locations for ETS transcription factors in their enhancer or promoter regions (Gambarotta et al., 1996; Rodrigo et al., 1999). ELF3 (Oettgen et al.,1997) is one of the differentially expressed genes between monophasic and biphasic tumors (Allander et al., 2002), increasing the possibility that ELF3 gene might have a dominant role in SS epithelial differentiation, specifically its overexpression might be associated with glandular epithelial differentiation in SS cases. Moreover, ELF3 gene shows differentially over-expression in biphasic tumors, compared with the monophasic ones (Allander et al., 2002).

Oncogenic progression in sarcomas can be distinguished into two separate groups, cytogenetically. The first concerns sarcomas that show a discrete, definite chromosomal translocation, such as SS (t18:X) (q11; q11), Ewing sarcoma (t11:22) (q24; q12), myxoid chondrosarcoma (t 9:22) (q22; q12), alveolar rhabdomyosarcoma (t 2:13) (q35; q14), clear cell sarcoma (t12: 22) (q13-q14; q12), dermatofibrosarcoma protuberans [ring 17 or t(17;22) (q24;q12)], and desmoplastic small round cell tumor (t 11:22) (p13; q25), whereas the second one contains sarcomas with complex karyotypes.

It is possible that multiple genetic alterations are responsible for the mentioned complex sarcomas, each of which leads to a biologic survival advantage for the malignant cell. Inversely, sarcomas such as SS depend on a discrete genetic alteration that is the dominant event and has an intense effect on the malignant cells phenotype (Dei Tos and Dal Cin, 1997).

\section{The Effect of E-Cadherin Inactivation in Synovial Sarcoma Pathogenesis}

E-cadherin, is a cell-cell adhesion molecule, it performs vital operations in the biological processes of embryogenesis and tissue architecture as it is responsible for intercellular junction complexes formation, and cell polarization (Takeichi, 1993; Overduin et al., 1995; Hirohashi et al., 1998). The extracellular domain of E-cadherin acts as a molecular barrier that mediates cell-cell adhesion, whereas the cytoplasmic tail is connected to cytoskeleton of actin across catenins (Ozawa et al., 1990). Ecadherin expression loss is involved in the invasive and metastatic properties of malignant cells (Kemler, 1993; Takeichi, 1993; Hirohashi et al., 1998).

E-cadherin downregulation is observed during epithelial-mesenchymal transitions (EMT), a 
process of cellular morphological alterations in epithelial cells. Epithelial and mesenchymal cells differ in phenotype as well as function, though both share inherent plasticity. Epithelial cells express high levels of E-cadherin, whereas mesenchymal cells express N-cadherin, fibronectin and vimentin. Thus, EMT entails profound morphological and phenotypic changes to a cell and leads to a representative fibroblastic and flattened phenotype (Batlle et al.,2000; Cano et al., 2000; Locascio et al., 2002; Nieto, 2002; Thiery, 2002).

Several mechanisms are involved in the impairment of E-cadherin function. Mutations are responsible for E-cadherin inactivation, and have been revealed in diverse tumors and cancer cell lines (Berx et al., 1995; Machado et al., 1999; Saito et al., 2001; Endo et al., 2001). Reduced E-cadherin expression is responsible for cellular morphological alterations in epithelial cells, and leads to an altered phenotype, as mentioned above (Frixen et al., 1991; Vleminckx et al.,1991; Batlle et al.,2000; Cano et al., 2000; Locascio et al., 2002; Nieto, 2002; Thiery, 2002). Its expression in some sarcomas, especially in biphasic SS glandular structures has found to be to a large extent limited (Saito et al., 2000; Yoo et al., 2002; Laskin and Miettinen, 2002).

SS spindle cell element often indicates histological characteristics that closely are similar to those of other sarcomas spindle cell such as Malignant Fibrous Histiocytoma, Leiomyosarcoma, and Malignant Peripheral Nerve Sheath Tumors (MSNST), although sarcomas with spindle cell component other than SS rarely display morphological epithelial differentiation (Saito et al., 2004). Genetic and epigenetic alterations act as potential mechanisms for E-cadherin inactivation as are responsible for E-cadherin gene silencing. Such mechanisms have been examined in SS cases. Missense mutation of E-cadherin gene has been revealed in some SS cases resulting in E-cadherin gene inactivation and leading to the monophasic spindle cell histological subtype of SS (Saito et al., 2004).

E-cadherin missense mutation and gene promoter hypermethylation have been detected evenly in $12.5 \%$ of SS cases, and the first finding was found only in monophasic histological subtype that contains SYT-SSX1 fusion gene, whereas in only one of which its expression was silenced. Moreover, the presence of unmethylated zones in samples that contained E-cadherin gene promoter methylation, increased the possibility that E-cadherin methylation status might be heterogeneous within distinct monophasic tumors. On the other hand, E-cadherin promoter methylation status could be different in different cell types, epithelial and spindle cells, in biphasic tumors (Saito et al., 2004). A supposed cause-effect relation between E-cadherin inactivation by missense mutation or promoter hypermethylation and SS histological morphology was proposed based on similar findings in gastric and breast cancer specific subtypes (Berx et al., 1995; Machado et al., 1999; Saito et al., 2001). 
Saito, et al. (Saito et al., 2004) revealed SYT-SSX1 fusion in all SS cases that comprised E-cadherin missense mutations, finding that might explain why that fusion could indicate either a monophasic or a biphasic phenotype. SS cells morphological transitions could be similar to EMTs in other biological systems. However, it remains unclear whether E-cadherin expression loss is a differentiation passive result or whether it might play a supplementary causal role in the spindle cell morphology differentiation in SS cases.

Another mechanism of downregulation of E-cadherin expression except genetic and epigenetic alterations is the process of transcriptional repression. E-cadherin downregulation is correlated with the glandular epithelial differentiation loss or absence in some SS cases. Moreover, E-cadherin expression loss is linked with histologic and molecular variety in SS cases (Saito et al., 2004).

\section{Overexpression of Snail transcription Factor as a E-cadherin Inactivation Mechanism in Synovial Sarcoma}

Snail is a family of transcription factors that promote the repression of the adhesion molecule Ecadherin to regulate EMT during embryonic development. It is responsible for blocking the E- cadherin gene expression by binding directly to the E-boxes that are present in the proximate promoter of Ecadherin. Fibroblasts and some epithelial tumor cells are responsible for its expression. (Batlle et al., 2000; Cano et al., 2000). An inverse relation between expression of endogenous E-cadherin and expression of endogenous Snail has been recorded (Nieto, 2002; Thiery, 2002), how- ever there are no published findings in the cases of sarcomas.

mRNA expression of E-cadherin in SS cases is correlated with reduced expression levels of Snail, finding that is consequent with the probability of E-cadherin transcriptional repression by Snail in those cases (Saito et al., 2004). The mentioned transcriptional repression of E-cadherin in SS cases can lead to downregulation of E-cadherin expression, however these mechanisms require confirmation regarding the functional level. E-cadherin expression might be arranged by molecular switching through Snail, leading the SS tumor cells differentiation to an epithelial phenotype. That inverse association between E-cadherin and Snail in SS cases is indirect as SS tumor cells with epithelial features will have the trend to express restricted levels of mesenchymal-associated proteins such as Snail (Saito et al., 2004).

Chromatin-mediated effects such as chromatin remodeling and chromatin modification are an additional possible level of E-cadherin expression control (Brown, 2003). The possible E-cadherin expression regulation by Snail and its silencing by missense mutation may play a crucial role in understanding the SS phenotypic heterogeneity (Saito et al., 2004).

Allander, et al. suggested that epithelial-related genes silencing, such as E-cadherin gene, might be 
responsible for the acquirement or maintenance of the SS spindle cell morphology (Allander et al., 2002).

The inverse association between Snail and E-cadherin, (Nieto, 2002; Thiery, 2002), proposes the ability of E-cadherin transcriptional repression by Snail in SS cases, finding that has been observed in epithelial malignancies but not in sarcomas. In addition, the EMT process can actually be a reversible process, as it occurs several times during embryonic development process (Sefton et al., 1998; Auersperg et al., 1999). E-cadherin reexpression occurs in the metastatic process in which the migrant malignant cells must install connection to their destination tissue (Mareel et al., 1991; Bukholm et al., 2000; Graff et al., 2000). Those observations may indicate that loss of E-cadherin expression has a causal role in SS spindle cell morphology acquirement, and is in accordance with the previous finding of inactivation of E- cadherin gene through missense mutations in some monophasic SS cases (Saito et al., 2001).

A comparison was carried out regarding the expression of E-cadherin and ELF3 transcript levels with the type of SYT-SSX fusion, to assess them as possible epithelial-specific downstream target genes of the fusion examined. The outcomes showed no correlation between their expression at the RNA level and type of SYT-SSX fusion. The exact role of ELF3 expression in SS cases is presently unknown, however its increased level of expression in biphasic SS cases suggests a possible role in epithelial glandular differentiation process (Saito et al., 2004). Among biphasic SS may be required supplementary events for SS tumor cells with E-cadherin protein expression to indicate glandular differentiation, such as the remodeling of the extracellular matrix (Saito et al., 2002).

Possible Role of Epidermal Growth Factor Receptor and HER-2/neu Expression in Synovial Sarcoma Pathogenesis

The human Epidermal Growth Factor Receptor (EGFR, ERBB) family of Receptor Tyrosine Kinases (RTK) is a critical group of mediators that are involved in survival, cell proliferation, differentiation, migration, and adhesion (Yarden, 2001). The family contains four distinct receptors, EGFR (ErbB1, HER1), ErbB2 (HER2, neu in rodents), ErbB3 (HER3), and ErbB4 (HER4) that are stimulated by a diversity of ligands, whereas it has not been identified a known ligand for HER-2/neu. A variety of neoplasms in several organs is characterized by EGFR expression (Dorkin et al., 1997; Nemoto et al., 1997; Kersemaekers et al., 1999), and HER-2/neu expression is amplified in a diversity of primary human carcinomas (Natali et al., 1990; Bongiorno et al., 1994; Cirisano and Karlan, 1996) and lung carcinomas. 
Little information is available regarding the ERBB family expression in SS cases. A robust EGFR membrane expression in two SS cases was detected (Gusterson, 1985). In a previous analysis of eight monophasic SS specimens using spotted cDNA expression profiling was found the clustering of EGFR with the SSX genes, proposing that this RTK may be associated with SS-specific expression (Nielsen et al., 2002). Previous researches (Nielsen et al., 2003; Barbashina et al., 2002) recorded the immunopositivity of SS cases compared to other soft tissue sarcomas. Similar studies investigated the HER-2/neu expression in SS cases. Allander, et al. (Allander et al., 2002) explored differences between SS and Malignant Fibrous Histiocytoma regarding gene profiling using array technology, and revealed increased HER-2/neu expression in the SS cohort.

However, the mentioned reports were not in agreement with a previous study that examined a large cohort of pediatric sarcomas in which was showed that HER-2/neu overexpression was a rare event in mesenchymal tumors including SS (George et al., 1992). It is obvious that EGFR and HER-2/neu expression in SS cases is controversial.

Dafydd, et al. analyzed 38 SS cases for assessing EGFR and HER-2/neu expression using immunehistochemical and molecular methods and detected expression of both genes, although at relatively low levels in the larger part of cases examined (Dafydd et al., 2005). Those outcomes confirm the findings of previous reports (Gusterson et al., 1985; Allander et al., 2002; Nielsen et al., 2002; Nuciforo et al., 2003), however were in contrast with an immuno-histochemical study of sarcomas and small round cell tumors of childhood (George et al., 1992) in which none of the SS cases studied showed immunohistochemical staining for HER-2/neu.

Two previous researches focused on the SYT/SSX fusion type contribution to the EGFR and HER2/neu expression. A precondition for understanding the contribution of the SYT/SSX fusion type to the regulation of translation of EGFR and HER-2/neu expression, is the two gene products normal function.

Native SYT links with p300/CBP in G1 arrested cells, and leads to the activation of 1 integrin (Eid et al., 2000). Activated 1 integrin regulates cell adhesion. The SSX genes group on X chromosome are responsible for encoding proteins that indicate strong expression in normal thyroid and testes (Crew et al., 1995), in addition to malignant tumors, such as melanomas (dos Santos et al., 2000). In those SYT/SSX fusion proteins, the binding of SYT to p300/ CBP is maintained whereas the adhesion function is lost (Eid et al., 2000).

It is possible that $S Y T / S S X$ mediates its action through configuration of other proteins responsible for transcription and translation. As mentioned the SYT/SSX fusion protein binds to the p300/CBP 
complex, process that is implicated in the HER-2/neu gene transcriptional regulation (Chen and Hung, 1997).

It has also been demonstrated the wide-ranging transcription of EGFR and HER-2/neu gene but suggested the absence of translation regulation, mainly in SS specimens comprising the SYT/SSX1 fusion gene. This was unexpected as SSX1 and SSX2 genes are almost similar in amino acid synthesis. Moreover, the SYT/SSX fusion protein was not directly responsible for the mentioned lack of translational regulation. The researchers also concluded that EGFR and HER-2/neu expression may constitute an important molecular event in SS pathogenesis (Dafydd et al., 2005).

\section{Tonsillar Synovial Sarcoma}

SS may appear in rare sites such as masticator space, tongue, sinonasal cavity, and trachea (Shmookler et al., 1982; Meer et al., 2003; Vogel et al., 2010; Villarroel-Salinas et al., 2012). However, primary tonsillar SS has been previously documented in only a few cases (Khademi et al., 2010; Vogel et al., 2010; Soria-Cespedes et al., 2013) mainly in young males with an age range of 19-35 years. In all of those cases the tumors were histologically biphasic, but only one showed poor differentiation areas. The tumor cells show strong, diffuse, positive nuclear staining for the TLE1antibody (transducin like enhancer of split1)/E (sp1), which is a highly susceptible marker of SS (Valente et al., 2013). This antibody homolog, Drosophila co-repressor groucho (Gro) is one of four members of the TLE gene family associated with embryogenesis, neuronal and epithelial differentiation, and hematopoiesis (Fraga et al., 2008; Kosemehmetoglu et al., 2009; Valente et al., 2013). TLE1 is a transcriptional corepressor that binds to a number of transcription factors and is implicated in the WNT/b-catenin signaling pathway, which is known to be associated with SS cases (Pretto et al., 2006). TLE1 positive nuclear expression has been detected at a rate higher than $90 \%$ of SS cases, formally in more than $50 \%$ of the cells (Coindre et al., 2003; Kosemehmetoglu et al., 2009; Valente et al., 2013). Lower levels of positive staining for TLE1 can be observed in other mesenchymal tumors that can mistakenly be considered as SS, and are Ewing sarcomas, schwannomas, Malignant Peripheral Nerve Sheath Tumor (MPNST), and malignant fibrous histiocytomas (Terry et al., 2007). Consequently, TLE1 should be used in combination with antibodies and other biomarkers such as keratins, EMA, Bcl-2, and CD34 (Kosemehmetoglu et al., 2009; Valente et al., 2013).

The diagnosis requires additional immune-histochemical and in some cases cytogenetic examination. No immuno-reactivity has been described for actin (HHF-35), myoglobin, CD34, or desmin (Frisman, 2012). 
In monophasic SS, the tumor is consisted of closely packed spindle cells with inadequate pale cytoplasm that form variably arranged bundles. Immuno-histochemically, the spindled cells were immune-reactive for cytokeratin OSCAR, EMA, Bcl-2, vimentin, CD99, and PGP 9.5, and showed a strong nuclear expression of TLE1. A small quantity of glandular-like formations can be identified focally that are able to react positively to cytokeratin OSCAR and EMA (Soria-Cespedes et al., 2013). The S-100 protein, another tumor marker may be focally expressed in up to $21 \%$ of tumors (Coindre et al., 2003). Moreover, histopathologic examination of monophasic SS showed occasional glandlike structures against a sarcomatous background. Immuno-histochemical study for cytokeratin revealed positive staining in the scattered epithelial component and that for vimentin revealed positive staining in the sarcomatous cells of the tumor (Khademi et al., 2010).

FISH is positive for the SYT (SS18) rearrangement, confirming the diagnosis of monophasic SS (Vogel et al., 2007; Sharma et al., 2021).

Biphasic SS cases consisted of intersecting bundles of spindle cells with few foci of groups of cuboidal cells/tubules (epitheloid component). Mild pleomorphism with numerous mitosis have also been revealed. CD99, CK, EMA, CD55, CD57 and Bcl-2 were positive, and Ki-67 was positive in 50\% of SS cases (Silambu V et al., 2020). Biphasic SS morphology may contain wide regions of spindle cells that are positive for vimentin, Bcl-2, CD99, and calponin intermixed with glandular structures positive for EMA cytokeratin (AEA1/3), bcl2, and CD99 (Vogel et al., 2010; Khademi et al., 2010).

Immuno-histochemical examination of biphasic SS for Pan CK, CK19, CK18, CK7 showed positive staining in the epithelial component and staining for vimentin showed positive staining in the mesenchymal component, whereas neural and muscle markers were negative (Vogel et al.,2010; Khademi et al., 2010).

Poorly differentiated tumors have rarely been described (De Silva et al., 2003), however in such cases was observed a mixture of epithelioid and spindle cells that were unreactive for cytokeratin, CD34, actin, and desmin. The mitotic index was increased and the proliferative activity based on ki67 staining was up to $50 \%$ (Vogel et al., 2010).

\section{Conclusion}

SS of palatine tonsil is a rare and extremely malignant tumor, thus the investigation of its molecular biology and development pathways could improve the patients' survival rate and prognosis. 


\section{References}

Allander SV, Illei PB, Chen Y, Antonescu CR, Bittner M, Ladanyi Mand Meltzer PS. Expression profiling of synovial sarcoma by cDNA microarrays: association of ERBB2, IGFBP2, and ELF3 with epithelial differentiation. Am J Pathol 2002; 161: 1587-1595.

Antonescu CR, Kawai A, Leung DH, Lonardo F, Woodruff JM, Healey JH, Ladanyi M. Strong association of SYT-SSX fusion type and morphologic epithelial differentiation in synovial sarcoma. Diagn Mol Pathol 2000; 9: 1-8.

Auersperg N, Pan J, Grove BD, Peterson T, Fisher J, Maines Bandiera S, Somasiri A, Roskelley CD. E-cadherin induces mesenchymal-to-epithelial transition in human ovarian surface epithelium. Proc Natl Acad Sci USA 1999; 96: 6249-6254.

BarbashinaV, Benevenia J, Aviv H, Tsai J, Patterson F, Aisner S, Cohen S, Fernandes H, Skurnick J, Hameed M. Oncoproteins and proliferation markers in synovial sarcomas: a clinico-pathologic study of 19 cases. J Cancer Res Clin Oncol 2002;128: 610-616.

Batlle E, Sancho E, Franci C, Dominguez D, Monfar M, Baulida J, Garcia De Herreros A. The transcription factor snail is a repressor of E- cadherin gene expression in epithelial tumour cells. Nat Cell Biol 2000; 2: 84-89.

Berx G, Cleton-Jansen A-M, Nollet F, de Leeuw WJF, van de Vijver MJ, Cornelisse C, van Roy F. E-cadherin is a tumour/invasion suppressor gene mutated in human lobular breast cancers. EMBO J 1995; 14: 6107-6115.

Bongiorno PF, Whyte RI, Lesser EJ, Moore JH, Orringer MB, Beer DG. Alterations of K-ras, p53, and erbB-2/neu in human lung adenocarcinomas. J Thorac Cardiovasc Surg 1994; 107: 590-595.

Brett D, Whitehouse S, Antonson P, Shipley J, Cooper C, Goodwin G. The SYT protein involved in the t(X;18) synovial sarcoma translocation is a transcriptional activator localised in nuclear bodies. Hum Mol Genet 1997; 6:1559 -1564.

Brown DT. Histone H1 and the dynamic regulation of chromatin function. Biochem Biochem Cell Biol 2003; 81:221-227.

Bruijn DRH, Baats E, Zechner U, de Leeuw B, Balemans M, Weghuis Olde D, Hirning Folz U, Geurts van Kessel A. Isolation and characterization of the mouse homolog of $S Y T$, a gene implicated in the development of human synovial sarcomas. Oncogene 1996; 13: 643-648.

Bukholm IK, Nesland JMand Borrensen-Dale AL. Re-expression of E-cadherin, alpha- catenin and beta-catenin, but not of gamma-catenin. J Pathol 2000; 190: 15-19.

Cano A, Perez-Moreno MA, Rodrigo I, Locascio A, Blanco MJ, del Barrio MG, Portillo F, Nieto MA. The transcription factor snail controls epithelial-mesenchymal transitions by repressing E-cadherin expression. Nat Cell Biol 2000; 2: 76-83.

Chand A, Clark J, Cooper CS, Craig IW. Long-range organization of reiterated sequences, including the SSX1 cDNA at the OATL1 cluster in Xp11.23. Genomics 1995; 30: 545-552.

Chen H and Hung MC. Involvement of co-activator p300 in the transcriptional regulation of the HER-2/neu gene. J Biol Chem 1997; 272: 6101-6104.

Cirisano FD and Karlan BY. The role of the HER-2/neu oncogene in gynecologic cancers. J Soc Gynecol Invest 1996; 3: 99105.

Clair JM, Arshi A, Abemayor E, John MS. Factors associated with survival in patients with synovial cell sarcoma of the head and neck: An analysis of 167 cases using the SEER (Surveillance, Epidemiology, and End Results) Database. JAMA Otolaryngol Head Neck Surg 2016; 142: 576-583.

Clark J, Rocques PJ, Crew AJ, Gill S, Shipley J, Chan AM, Gusterson BA, Cooper CS. Iden- tification of novel genes, SYT and 
SSX, involved in the $\mathrm{t}(\mathrm{X} ; 18)(\mathrm{p} 11.2 ; \mathrm{q} 11.2)$ translocation found in human synovial sarcoma. Nat Genet 1994; 7: $502-508$.

Coindre JM, Pelmus M, Hostein I, Lussan C, Bui BH, Guillou L. Should molecular testing be required for diagnosing synovial sarcoma? Cancer 2003; 98: 2700-2707.

Crew J, Clark J, Fisher C, Gill S, Grimer R, Mitchell P. Fusion of SYT to two genes, SSX1 and SSX2, encoding proteins with homology to the Kruppel associated box in human synovial sarcoma. EMBO J 1995; 14: 2333-2340.

Dafydd GT, Giordano TJ, Sanders D, Biermann S, Sondak VK., Trent JC, Yu D, Pollock RE, Baker L. Expression of Receptor Tyrosine Kinases Epidermal Growth Factor Receptor and HER- 2/neu in Synovial Sarcoma. Cancer 2005; 15; 103: 830-838.

de Leeuw B, Balemans M, Geurts van Kessel A. A novel Krüppel-associated box containing the SSX gene (SSX3) on the human X chromosome is not implicate in $\mathrm{t}(\mathrm{X} ; 18)$-positive sy- novial sarcomas. Cytogenet Cell Genet 1996; 73: 179-183.

de Leeuw B, Balemans M, Olde Weghuis D, Geurts van Kessel A: Identification of two alternative fusion genes, SYT-SSX1 and SYTSSX2, in t(X;18) (p11.2; q11.2)-positive synovial sarco- mas. Hum Mol Genet 1995; 4: 1097-1099.

de Leeuw B, Suijkerbuijk RF, Olde Weghuis D, Meloni AM, Stenman G, Kindblom LG, Balemans M, van den Berg E, Molenaar WM, Sandberg AA. Distinct Xp11.2 breakpoint regions in synovial sarcoma revealed by metaphase and interphase FISH: relationship to histologic subtypes. Cancer Genet Cytogenet 1994; 73: 89-94.

De Silva MV, McMahon AD, Paterson L, Reid R. Identification of poorly differentiated synovial sarcoma: a comparison of clinicopathological and cytogenetic features with those of typical synovial sarcoma. Histopathology 2003; 43: 220-230.

Dei Tos AP and Dal Cin P. The role of cytogenetics in the classification of soft tissue tu- mours. Virchows Arch A 1997; 431: 83-94.

Dei Tos AP, Dal CP, Sciot R, Furlanetto A, Rinaldo A, Dal Cin P, Da Mosto MC, Ferlito A. Synovial sarcoma of the larynx and hypopharynx. Ann Otol Rhinol Laryngol 1998; 107: 1080-1085.

Dorkin TJ, Robson CN, Neal DE. The molecular pathology of urological malignancies. J Pathol 1997; 183: $380-387$.

dos Santos NR, de Bruijn DRH, Balemans M, Janssen B, Gärtner F, Lopes JM, de Leeuw B, van Kessel AG. Nuclear localization of SYT, SSX and the synovial associated SYT-SSX fusion proteins. Hum Mol Genet 1997; 6: 1549-1558.

dos Santos NR, Torensma R, de Vries TJ, Schreurs MW, de Bruijn DR, Kater-Baats E, Ruiter DJ, Adema GJ, van Muijen GN, van Kessel AG. Heterogeneous expression of the SSX cancer/ testis antigens in human melanoma lesions and cell lines. Cancer Res 2000; 60: 1654-1662.

Eid JE, Kung AL, Scully R, Livingston DM. p300 interacts with the nuclear proto- oncoprotein SYT as part of the active control of cell adhesion. Cell 2000; 102: 839-848.

Eilber FC and Dry SM. Diagnosis and management of synovial sarcoma. J Surg Oncol 2008; 97:314-320.

Endo K, Ashida K, Miyake N, Terada T. E-cadherin gene mutations in human intra- hepatic cholangiocarcinoma. J Pathol 2001; 193: 310-317.

Enzinger FM and Weiss SW. Enzinger and Weiss's Soft Tissue Tumors, 4th ed. St Louis: Mosby; 2001.

Fisher C, de Bruij DRH, Geurts van Kessel A. World health organization classification of tumours. Synovial sarcoma. In: Fletcher CDM, Krishnan Unni K, Mertens F, editors. Tumors of soft tissue and bone. Lyon: IARCPress 2002; pp: 200-204.

Fisher C. Synovial sarcoma: ultrastructural and immunohistochemical features of epithelial differentiation in monophasic and biphasic tumors. Hum Pathol 1986; 17: 996-1002. 
Fraga MF, Bardasco M, Ballester E, Ropero S, Lopez-Nieva P, Lopez-Serra L, Martín- Subero JI, Calasanz MJ, de Silanes IL, Setien F, Casado S, Fernandez AF, Siebert R, Stifani S, Esteller M. Epigenetic inactivation of the groucho homologue TLE1 in hematologic malignancies. Cancer Res 2008; 68: 4116-4122.

Frisman DM. Synovial Sarcoma. (Immunoquery/Immunohistochemistry Literature Database Query System web site). Available at: http://my.statdxcom/PathIQ/PanelAb.do. Accessed Dec 2012.

Frixen UH, Behrens J, Sachs M, Eberle G, Voss B, Warda A, Lochner D, Birchmeier W. E-cadherin-mediated cell-cell adhesion prevents invasiveness of human carcinoma cells. J Cell Biol 1991; 113: 173-185.

Gaertner E, Zeren EH, Fleming MV, Colby TV, Travis WD. Biphasic synovial sarcomas arising in the pleural cavity. Am J Surg Pathol 1996; 20: 36-45.

Gambarotta G, Boccaccio C, Giordano S, Ando M, Stella MC, Comoglio PM. Ets up- regulates MET transcription. Oncogene 1996; 13: 1911-1917.

George E, Niehans GA, Swanson PE, Strickler JG, Singleton TP. Overexpression of the c-erbB-2 oncogene in sarcomas and small round-cell tumors of childhood. An Immunohistochem Invest Arch Pathol Lab Med 1992; 116: 1033-1035.

Graff JR, Gabrielson E, Fujii H, Baylin SB, Herman JG. Methylation patterns of the E- cadherin 5' CpG island are unstable and reflect the dynamic, heterogeneous loss of E-cadherin ex- pression during metastatic progression. J Biol Chem 2000; 275: 2727-2732.

Gure AO, Tureci O, Sahin U, Tsang S, Scanlan MJ, Jager E, Knuth A, Pfreundschuh M, Old LJ, Chen YT. SSX: a multigene family with several members transcribed in normal testis and human cancer. Int J Cancer 1997; 72: 965-971.

Gusterson B, Cowley G, Mcllhinney J, Ozanne B, Fisher C, Reeves B. Evidence for in- creased epidermal growth factor receptors in human sarcomas. Int J Cancer 1985; 36: 689-693.

Hirohashi S. Inactivation of the E-cadherin-mediated cell adhesion system in hu- man cancers. Am J Pathol 1998; 153 : 333-339.

Kato H, Tjernberg A, Zhang W, Krutchinsky AN, An W, Takeuchi T, Ohtsuk Y, Sugano S, R de Bruijn D, Chait BT, Roeder RG. SYT associates with human SNF/SWI complexes and the C-terminal region of its fusion partner SSX1 targets histones. J Biol Chem 2002; 277: 5498-5505.

Kawai A, Woodruff J, Healey JH, Brennan MF, Antonescu CR, Ladanyi M. SYT-SSX gene fusion as a determinant of morphology and prognosis in Synovial sarcoma. N Engl J Med 1998; 338: 153-160.

Kemler R. From cadherins to catenins: cytoplasmic protein interactions and regulation of cell adhesion. Trends Genet 1993; 9: 317-321.

Kersemaekers AM, Fleuren GJ, Kenter GG, Van den Broek LJ, Uljee SM, Hermans J, Van de Vijver MJ. Oncogene alterations in carcinomas of the uterine cervix: overexpression of the epidermal growth factor receptor is associated with poor prognosis. Clin Cancer Res 1999; 5: 577-586.

Khademi B, Bahranifard H, Mohammadianpanaht M, Javad Ashraf M, Azarpira N, Dehghani M. Synovial Sarcoma of the Palatine Tonsil: Report of Two Cases and Review of the Literature. Middle East Journal of Cancer 2010; 1: 141-146.

Kosemehmetoglu K, Vrana JA, Folpe AL. TLE1 expression is not specific for synovial sarcoma: a whole section study of 163 soft tissue and bone neoplasms. Mod Pathol 2009; 22: 872-878.

Ladanyi M, Antonescu CR, Leung DH, Woodruff JM, Kawai A, Healey JH, Brennan MF, Bridge JA, Neff JR, Barr FG, Goldsmith JD, Brooks JSJ, Goldblum JR, Ali SZ, Shipley J, Cooper CS, Fisher C, Skytting B, Larsson O. Impact of SYT-SSX fusion type on the clinical behaviour of synovial sarcoma: a multi institutional retrospective study of 243 patients. Cancer Res 2002; 62: 
135-140.

Ladanyi M. Fusions of the SYT and SSX genes in synovial sarcoma. Oncogene 2001; 20: 5755-5762.

Ladanyi M. The emerging molecular genetics of sarcoma translocations. Diagn Mol Pathol 1995; 4: 162-173.

Laskin WB and Miettinen M. Epithelial-type and neural-type cadherin expression in malignant non carcinomatous neoplasms with epithelioid features than involve the soft tissues. Arch Pathol Lab Med 2002; 126: 425-431.

Lim FL, Soulez M, Koczan D, Thiesen HJ, Knight JC. A KRAB-related domain and a novel transcription repressor domain in proteins encoded by SSX genes that are disrupted in hu- man sarcomas. Oncogene 1998; 17: 2013-2018.

Locascio A, Vega S, de Frutos CA, Manzanares M, Nieto MA. Biological Potential of a Functional Human SNAILRetrogene. J Biol Chem 2002; 277: 38803-38809.

Machado JC, Soares P, Carneiro F, Rocha A, Beck S, Blin N, Berx G, Sobrinho-Simoes M. E-cadherin gene mutations provide a genetic basis for the phenotypic divergence of mixed gastric carcinomas. Lab Invest 1999; 79: $459-465$.

Mareel M, Behrens J, Birchmeier W, De Bruyne GK, Vleminckx K, Hoogewus A, Fiers WC and van Roy F. Down-regulation of E-cadherin expression in Madin Darby canine kidney (MDCK) cells inside tumors of nude mice. Int J Cancer 1991; 47: 922928.

Meer S, Coleman H, Altini M. Oral synovial sarcoma: a report of 2 cases and a review of the literature. Oral Surg Oral Med Oral Pathol Oral Radiol Endod 2003; 96: 306-315.

Meis-Kindblom JM, Stenman G, Kindblom LG. Differential diagnosis ofsmall round cell tumors. Semin Diagn Pathol 1996; 13: 213-241.

Muthamil Silambu V. A rare case of synovial sarcoma of tonsil. Department of ENT, Stanley Medical College and Hospital. University Journal of Surgery and Surgical Specialties 2020; 6: 1

Nagai M, Tanaka S, Tsuda M, EndoS, Kato H, Sonobe H, Minami A, Hiraga H, Nishihara H, Sawa H, Nagashima K. Analysis of transforming activity of human synovial sarcoma-associated chimeric protein SYT-SSX1 bound to chromatin remodeling factorhBRM/hSNF2 alpha. Proc Natl Acad Sci USA 2001; 98: 3843-3848.

Nagayama S, Katagiri T, Tsunoda T, Hosaka T, Nakashima Y, Araki N, Kusuzaki K, Nakayama T, Tsuboyama T, Nakamura T, Imamura M, Nakamura Y, Toguchida J. Genome-wide analysis of gene expression in synovial sarcomas using a cDNA microarray. Cancer Res 2002; 62: 5859-5866.

Natali PG, Nicotra MR, Bigotti A, Venturo I, Slamon DJ, Fendly BM, Ullrich A. Expression of the p185 encoded by HER2 oncogene in normal and transformed human tissues. Int J Cancer 1990; 45: 457-461.

Nemoto T, Ohashi K, Akashi T, Johnson JD, Hirokawa K. Overexpression of protein tyrosine kinases in human esophageal cancer. Pathobiology 1997; 65: 195-203.

Nielsen TO, Hsu FD, O’Connell JX, Blake Gilks C, Sorensen PHB, Linn S, West RB, Long Liu C, Botstein D, Brown PO, van de Rijn M. Tissue microarray validation of epidermal growth factor receptor and SALL2 in synovial sarcoma with comparison to tumors of similar histology. Am J Pathol 1997; 2003; 163: 1449-1456.

Nielsen TO, West RB, Linn SC, Alter 0, Knowling MA, O’Connell JX, Zhu S, Fero M, Sheriock G, Pollack JR, Brown PO, Botstein D, van de Rijn M. Molecular characterization of soft tissue tumours: a gene expression study. Lancet 2002; 359: 13011307.

Nieto MA. The snail superfamily of zinc-finger transcription factors. Nat Rev Mol Cell Biol 2002; 3: 155-166. 
Noguchi S, Ueki T, Kawauchi S, Fukuda T, Matsuura H, Sonoda T, Tsuneyoshi M. Establishment and characterization of a new synovial sarcoma cell line, SN-SY-1: special reference to bcl-2 protein and SYT-SSX1 hybrid transcripts. Int J Cancer 1997; 72: 995-1002.

Nuciforo PG, Pellegrini C, Fasani R, Maggioni M, Coggi G, Parafioriti A, Bosari S. Molecular and immunohistochemical analysis of HER2/neu oncogene in synovial sarcoma. Hum Pathol 2003; 34: 639-645.

Oettgen P, Alani RM, Barcinski MA, Brown L, Akbarali Y, Boltax J, Kunsch C, Mun- ger K, Libermann TA. Isolation and characterization of a novel epithelium-specific transcription factor, ESE-1, a member of the ets family. Mol Cell Biol 1997; 17: 4419-4433.

Okcu MF, Munsell M, Treuner J, Mattke A, Pappo A, Cain A, Ferrari A, Casanova M, Ozkan A, Raney B. Synovial sarcoma of childhood and adolescence: A multicenter, multivariate analysis of outcome. J Clin Oncol 2003; 21: 1602-1611.

Overduin M, Harvey TS, Bagby S, Tong KI, Yau P, Takeichi Mand Ikura M. Solution structure of the epithelial cadherin domain responsible for selective cell adhesion. Science 1995; 267: 386-389.

Ozawa M, Engel J, Kemler R. Single amino acid substitutions in one Ca2+ binding site of uvomorulin abolish the adhesive function. Cell 1990; 63: 1033-1038.

Pretto D, Barco R, Rivera J. The synovial sarcoma translocation protein SYT-SSX2 recruits beta-catenin to the nucleus and associates with it in an active complex. Oncogene 2006; 25: 9226-9235.

Rabbitts TH: Chromosomal translocation in human cancer. Nature 1994; 372: 143-149.

Renwick PJ, Reeves BR, Dal Cin P, Fletcher CDM, Kempski H, Sciot R, Kazmierczak B, Jani K, Sonobe H, Knight JC. Two categories of synovial sarcoma defined by diver-gent chromosome translocation breakpoints in Xp11.2, with implications for thehistologic sub-classification of synovial sarcoma. Cytogenet Cell Genet 1995; 70: 58-63.

Rodrigo I, Cato ACB, Cano A. Regulation of E-cadherin gene expression during tumor progression: the role of a new Etsbinding site and the E-pal element. Exp Cell Res 1999; 248: 358-371.

Saito T, Oda Y, Kawaguchi K, Sugimachi K, Yamamoto H, Tateishi N, Tanaka K, Matsuda S, Iwamoto Y, Ladanyi M, Tsuneyoshi M. E-cadherin mutation and Snail overexpression as alternative mechanisms of E-cadherin inactivation in synovial sarcoma. Oncogene 2004; 23: 8629- 8638.

Saito T, Oda Y, Sakamoto A, Tamiya S, Iwamoto Y, Tsuneyoshi M. Matrix metallo- proteinase-2 expression correlates with morphological and immunohistochemical epithelial chara- cteristics in synovial sarcoma. Histopathology 2002; 40: 279285.

Saito T, Oda Y, Sakamoto A, Tamiya S, Kinukawa N, Hayashi K, Iwamoto Y, Tsuneyoshi M. Prognostic value of the preserved expression of the E-Cadherin and catenin of the adhesion molecules and of beta-catenin mutations in synovial. $J$ Pathol 2000; 192: 342-350.

Saito T, Oda Y, Sugimachi K, Kawaguchi K, Tamiya S, Tanaka K, Matsuda S, Sakamoto A, Iwamoto Y, Tsuneyoshi M. Ecadherin gene mutations frequently occur in synovial sar- coma as a determinant of histological features. Am J Pathol 2001; 159: 2117-2124.

Sefton M, Sanchez S, Nieto MA. Conserved and divergent roles for members of the Snail family of transcription factors in the chick and mouse embryo. Development 1998; 125: 3111-3121.

Sharma A, Susan Ko J, Billings SD. Primary cutaneous synovial sarcoma -Some- times the hoof beats are zebras. J Cutan Pathol 2021; 48: 281-284.

Shipley J, Crew J, Birdsall S, Gill S, Clark J, Fisher C, Kelsey A, Nojima T, Sonobe H, Cooper C, Gusterson B. Interphas 
fluorescence in situ hybridization and reverse transcription polymerase chain reaction as a diagnostic aid for synovial sarcoma. Am J Pathol 1996; 148: 559-567.

Shipley JM, Clark J, Crew AJ, Birdsall S, Rocques PJ, Gill S, Chelly J, Monaco AP, Abe S, Gusterson BA, Cooper CS. The $\mathrm{t}(\mathrm{X} ; 18)$ (p11.2; q11.2) translocation found in human synovial sarcomas involves two distinct loci on the $\mathrm{X}$ chromosome. Oncogene 1994; 9: 1447-1453.

Shmookler BM, Enzinger FM, Brannon RB. Orofacial synovial sarcoma. Cancer 1982; 50: 269-276.

Smith HA and McNeel DG. The SSX Family of Cancer-Testis Antigens as Target Proteins for Tumor Therapy. Clin Dev Immunol 2010; 2010: 150591.

Soria-Cespedes D, Galván-Linares AI, Oros-Ovalle C, Gaitan Gaona F, Ortiz-Hidalgo C. Primary monophasic synovial sarcoma of the tonsil: Immunohistochemical and molecular study of a case and review of the literature. Head Neck Pathol 2013; 7: 400-403.

Soulez M, Saurin AJ, Freemont PS, Knight JC. SSX and the synovial-sarcoma-specific chimaeric protein SYT-SSX colocalize with the human Polycomb group complex. Oncogene 1999; 18: 2739-2746.

Sreekantiah C, Ladanyi M, Rodriguez E, Chaganti RSK. Chromosomal aberrations in soft tissue tumors: relevance to diagnosis, classification and molecular mechanisms. Am J Pathol 1994; 144: 1121-1133.

Takeichi M. Cadherins in cancer: implications for invasion and metastasis. Curr Opin Cell Biol 1993; 5: 806-811.

Terry J, Saito T, Subramanian S, Ruttan C, Antonescu CR, Goldblum JR, Downs- Kelly E, Corless CL, Rubin BP, van de Rijn M, Ladanyi M, Nielsen TO. TLE1 as a diagnostic immuno- histochemical marker for synovial sarcoma emerging from gene expression profiling studies. Am J Surg Pathol 2007; 31: 240-246.

Thaete C, Brett D, Monaghan P, Whitehouse S, Rennie G, Rayner E, Cooper CS, Goodwin G. Functional domains of the SYT and SYT-SSX synovial sarcoma translocation proteins and co-localization with the SNF protein BRM in the nucleus. Hum Mol Genet 1999; 8: 585-591.

Thiery JP. Epithelial-mesenchymal transitions in tumour progression. Nat Rev Cancer 2002; 2: 442-454.

Tsuji S, Hisaoka M, Morimitsu Y, Hashimoto H, Shimajiri S, Komiya S, Ushijima M, Nakamura T. Detection of SYTSSX fusion transcript in synovial sarcoma by reverse transcriptase polymerase chain reaction using archival paraffin embedded tissues. Am J Pathol 1998; 153: 1807-1812.

Turc-Carel C, Dal Cin P, Limon J, Rao U, Li FP, Corson JM, Zimmerman R, Parry DM, Cowan JM, Sandberg AA. Involvement of chromosome $\mathrm{X}$ in primary cytogenetic change in hu- man neoplasia: nonrandom translocation in synovial sarcoma. Proc Natl Acad Sci USA 1987; 84: 1981-1985.

Türeci Ö, Sahin U, Schobert I, Koslowski M, Scmitt H, Schild HJ, Stenner F, Seitz G, Rammensee HG, Pfreundschuh M. The SSX-2 gene, which is involved in the $\mathrm{t}(\mathrm{X} ; 18)$ translocation of synovial sarcomas, codes for the human tumor antigen HOM-MEL40. Cancer Research 1996; 56: 4766-4772.

Valente AL, Tull J, Zhang S. Specificity of TLE1 expression in unclassified high- grade sarcomas for the diagnosis of synovial sarcoma. Appl Immunohistochem Mol Morphol 2013; 21: 408-413.

Villarroel-Salinas J, Campos-Martınez J, Ortiz-Hidalgo C. Synovial sarcoma of the tongue confirmed by molecular detection of the SYT-SSX2 fusion gene transcript. Int J Surg Pathol 2012; 20: 386-389.

Vleminckx K, Vakaet Jr L, Mareel M, Fiers W, van Roy F. Genetic manipulation of E-cadherin expression by epithelial tumor cells reveals an invasion suppressor role. Cell 1991; 66: 107-119. 
Vogel U, Wehrmann M, Bültmann B. Synovial sarcoma of the left tonsil in a 31-year-old patient: report of a rare case. Diagnost Pathol 2007; 2: S17.

Vogel U, Wehrmann M, Eichhorn W, Bültmann B, Stiegler M, Wagner W. Mole- cular and clinicopathological findings in a tonsillar synovial sarcoma. A case study and review of the literature. Head Neck Pathol 2010; 4: 257-260.

Willeke F, Mechtersheimer G, Schwarzbach M, Weitz J, Zimmer D, Lehnert T, Herfarth C,von Knebel Doeberitz M, Ridder R. Detection of SYTSSX1/2 fusion transcripts by reverse transcriptase-Polymerase chain reaction (RT-PCR) is a valuable diagnostic tool in Synovial sarcoma. Eur J Cancer 1998; 34: 2087-2093.

Yakushiji T, Yonemura K, Tsuruta J, Nishida K, Kato T, Takagi K. Capacity for epithelial differentiation in synovial sarcoma: analysis of a new human cell line. J Clin Pathol 2000; 53: 525-531.

Yarden Y. The EGFR family and its ligands in human cancer. Signaling mecha- nisms and therapeutic opportunities. Eur J Cancer 2001; 37: S3-S8.

Yoo J, Park S, Kang CS, Kang SJ, Kim BK. Expression of E-cadherin and p53 proteins in human soft tissue sarcomas. Arch Pathol Lab Med 2002; 126: 33-38. 